\title{
PENGALAMAN HOSPITALISASI ANAK USIA SEKOLAH
}

\author{
Siti Chodidjah*, Elfi Syahreni \\ Fakultas Ilmu Keperawatan, Universitas Indonesia, J1. Prof. Bahder Djhohan, Depok 16424, Indonesia \\ *E-mail: s.chodidjah@ui.ac.id
}

\begin{abstract}
Abstrak
Mengalami sakit dan dirawat di rumah sakit merupakan pengalaman yang traumatik pada anak dan orang tua. Lingkungan rumah sakit yang asing, interaksi dengan pertugas kesehatan yang belum dikenal, berbagai prosedur diagnostik, dan pengobatan yang menimbulkan kecemasan menjadi faktor penyebab pengalaman traumatik tersebut. Pengalaman traumatik tersebut dapat dirasakan anak bahkan sampai bertahun-tahun setelah dipulangkan dan mempengaruhi perkembangan anak di masa mendatang. Riset ini merupakan riset dengan desain kualitatif yang bertujuan menggali pengalaman hospitalisasi anak usia sekolah. Data didapatkan dari wawancara dengan pertanyaan semi terstruktur pada sepuluh orang anak berusia 6-12 tahun yang sedang dirawat di ruang penyakit dalam anak dengan teknik pengambilan sampel purposive sampling. Analisis data dengan metode Vann Manen menemukan tema: terbatasnya melakukan aktivitas rutin sehari-hari, suasana ruang rawat tidak nyaman, tidak bebas menentukan keinginan, mengalami nyeri selama perawatan, dan menemukan cara mengatasi masalah selama dirawat. Penelitian ini merekomendasikan dilakukannya berbagai upaya untuk mencegah dampak negatif hospitalisasi pada anak.
\end{abstract}

Kata kunci: anak usia sekolah, hospitalisasi, pengalaman traumatik

\begin{abstract}
Hospitalization Experiences among School Age Children. Hospitalization can be a traumatic and stressful experience for children and also the parents. Unfamiliar environment and health personnel, diagnostic procedures and treatments have been identified as the stressor. The traumatic experiences following hospitalization might influence the children's well being until years after the hospitalization. This qualitative research aimed to explore children's experiences during hospitalization. Data were collected using purposive sampling technique from 10 hospitalized school-aged children in pediatric medical ward. Themes from qualitative analysis included: separation from family and peer, unfamiliar environment, loss of self determination, experience of pain, and health awareness. These research recomendates strategies to prevent negative effect of hospitalization.
\end{abstract}

Keywords: hospitalization, school age children. children's traumatic experiences

\section{Pendahuluan}

Saat ini telah terjadi pergeseran alasan hospitalisasi. Dahulu, anak mengalami hospitalisasi karena menderita penyakit akut dan dirawat untuk waktu yang relatif singkat. Saat ini banyak bayi dan anak-anak mengalami hospitalisasi karena penyakit kronik dan ketidakmampuan yang serius. Kemajuan ilmu dan teknologi memberikan kesempatan bagi anak-anak tersebut untuk bertahan hidup lebih lama, namun mereka membutuhkan perawatan yang lebih sering dan lebih intensif (James \& Ashwill, 2007).
Menjalani perawatan di rumah sakit dapat menjadi pengalaman yang tidak menyenangkan bagi anak dan orang tua. Secara umum, anak akan merasakan kecemasan karena perpisahan dengan orang tua/orang terdekat, kehilangan kontrol diri, dan ketakutan akan rasa sakit (Bowden \& Greenberg, 2010). Anak akan menangis, menjerit, dan menolak petugas kesehatan. Berada di lingkungan yang asing, petugas kesehatan yang asing, pelengkapan dan prosedur pengobatan dan pembedahan, perubahan aktivitas rutin, melihat kondisi sakit pasien lain, dan membuat anak kehilangan kontrol untuk melakukan aktivitas 
yang biasanya mereka lakukan. Kehilangan kontrol diri ini antara lain dimanifestasikan dengan regresi ke tahapan perkembangan sebelumnya dan pencapaian tugas perkembangan yang telah dicapai anak mungkin akan hilang (Basiri-Moghaddam, Sadeghmogaddam, \& Ahmadi, 2011). Karlings (2006) menambahkan adanya masalah negativistik, tempertantrum yang cenderung destruktif, ketergantungan terhadap orang tua, ketakutan terhadap dokter, perawat, dan rumah sakit pada anak pasca dirawat di rumah sakit.

Masalah-masalah yang terjadi pada saat anak mengalami hospitalisasi tersebut dapat berlanjut setelah anak sehat dan dipulangkan. Umumnya masalah-masalah tersebut mempengaruhi anak setelah anak dipulangkan dari perawatan dan menghilang sejalan dengan perjalanan waktu. Namun, penelitian oleh Rautava, Lehtonen, Heleneus, dan Sillanpaa (2003), pada bayi yang dihospitalisasi sejak baru dilahirkan menunjukkan bahwa dampak perubahan perilaku dan masalah keluarga baru menghilang setelah anak berusia dua belas tahun.

Meskipun demikian, selain meninggalkan dampak negatifterhadap psikologis anak, hospitalisasi juga dinilai dapat memberikan dampak positif terhadap anak. Mengalami sakit dan stres selama proses hospitalisasi memberikan kesempatan kepada anak untuk beradaptasi mengatasi masalah dan kecemasan yang dihadapi selama proses perawatan kesehatannya. Ketika anak mampu mengatasi masalah dan stres yang dihadapi, hal ini akan menumbuhkan keepercayaan diri yang tinggi pada anak. Selain itu, edukasi yang diberikan selama hospitalisasi juga dapat menjadi pembelajaran tentang kesehatan dan penyakitnya. Hal ini mungkin menimbulkan ketertarikan anak terhadap karir di bidang kesehatan (Wong \& Hockenberry, 2003). Ryan-Wegner dan Gardner (2012) menambahkan bahwa pengalaman hospitalisasi juga mempengaruhi pemanfaatan sarana kesehatan di masa depan. Pengalaman positif selama hospitalisasi membuat pemanfaatan sarana kesehatan untuk menjaga dan mempertahankan kesehatan menjadi lebih optimal.
Hospitalisasi juga dapat memberikan dampak positif terhadap orang tua. Hospitalisasi memberikan kesempatan bagi orang tua untuk lebih memahami tumbuh kembang anaknya dan membina ikatan antara orang tua dan anak, dan meningkatkan kemampuan parenting (Wong \& Hockenberry, 2003).

\section{Metode}

Penelitian ini merupakan penelitian kualitatif dengan pendekatan deskriptif fenomenologi. Data didapatkan dari sepuluh orang anak berusia 6-12 tahun, yang minimal telah mengalami perawatan selama satu hari dan maksimal lima hari di ruang penyakit dalam anak Jakarta Timur, mampu berkomunikasi dengan baik, dan dapat menceritakan pengalaman hospitalisasinya, serta mendapatkan perawatan dengan tindakan invasif minimal berupa pemasangan infus dan pemberian obat melalui pembuluh darah. Penilaian kemampuan komunikasi dilakukan dengan meminta rekomendasi perawat ruangan. Orang tua/pengasuh diikutsertakan dan dimintakan informasinya terutama jika anak kurang mampu mengomunikasikan pengalaman hospitalisasinya dengan baik.

Pengumpulan data dilakukan melalui wawancara semi terstruktur yang direkam dengan menggunakan tape recorder. Wawancara dilakukan di ruang rawat informan, dan berlangsung sekitar dua puluh sampai dengan tiga puluh delapan menit. Verbatim dari hasil wawancara kemudian dilakukan analisis meggunakan metode Vann Manen. Prinsip kepercayaan hasil penelitian dilakukan dengan melakukan triangulasi teknik dengan cara memvalidasi pengalamanan hospitalisasi yang diceritakan anak kepada orang tua yang mendampingi anak selama perawatannya.

\section{Hasil}

Penelitian ini menemukan lima tema pengalaman hospitalisasi pada anak usia sekolah. Tema tersebut adalah terbatasnya melakukan aktivitas rutin sehari-hari, suasana ruang rawat tidak nyaman, tidak bebas menentukan keinginan, mengalami 
nyeri selama perawatan, dan menemukan cara mengatasi masalah selama dirawat.

Terbatasnya melakukan aktivitas rutin seharihari. Mengalami keterbatasan melakukan aktivitas rutin sehari-hari dialami oleh semua anak. Keterbatasan beraktivitas yang dialami oleh anak meliputi keterbatasan melakukan aktivitas rutin dengan keluarga, teman, dan aktivitas sekolah. Dirawat di rumah sakit membuat anak tidak dapat melakukan aktivitas yang biasa mereka lakukan bersama anggota keluarganya. Anak menyatakan rasa kehilangannya karena tidak dapat lagi membantu ayah memasak atau mengaji bersama ayahnya.

"Di sini enggak bisa bantuin Abi masak...." (partisipan 3).

"Apalagi ditinggal orang tua, enggak diajak ngobrol gitu. Biasanya kan kalo sama ayah, kan, baca Alquran bareng...." (partisipan 10).

Anak menyatakan bahwa perawatan di rumah membuat mereka tidak dapat melakukan aktivitas yang biasa dilakukan bersama teman sekolah atau teman seperti bermain, mengobrol, dan jajan.

“ Enggak enak. Enggak bisa ngoborol, enggak bisa jajan bareng..” (partisipan 8).

"Enggak bisa main sama temen-temen..." (partisipan 9)

Hospitalisasi juga membuat anak kehilangan kesempatan untuk melakukan aktivitas yang biasa anak lakukan sehari-hari, seperti pergi ke sekolah dan belajar. Hal ini membuat anak mengalami kekhawatiran terhadap prestasi belajarnya, terutama pada anak yang berada di kelas enam.

"Soalnya udah kelas 6, entar kalo ujian gimana, takut nilainya jelek, takut ketinggalan pelajaran..." (partisipan 8).

"Enggak enak, enggak sekolah, enggak ketemu, itu ketinggalan pelajaran..” (partisipan 10).
Akan tetapi, tidak semua anak mengalami keterbatasan melakukan aktivitas rutin sehariharinya. Terdapat satu orang anak yang tidak mengalami dampak dari terpisahnya dengan orang tua dan teman bermainnya. Anak mengatakan bahwa pada saat ibunya pulang ke rumah karena suatu keperluan, perawat mengajaknya bermain sekolah-sekolahan, mewarnai, dan menulis. Anak menyatakan bahwa dirinya tetap bisa bermain dan mempunyai banyak teman di rumah sakit. Anak juga belajar matematika dengan ibunya. Pengalaman berbeda yang dialami anak ini disebabkan oleh ia sering mengalami hospitalisasi. Selain itu, anak tersebut termasuk anak yang ceria dan senang berinteraksi dengan orang lain.

Suasana ruang rawat tidak nyaman. Hampir semua anak merasakan ketidaknyamanan terhadap lingkungan ruang rawat. Ketidaknyamanan yang anak rasakan meliputi kebisingan suara dari pasien lain yang menangis atau suara orang mengobrol, ruang rawat yang panas, ruang perawatan intensif yang sangat dingin, serta sarana perawatan, seperti tempat tidur yang keras dan perlak pelapis yang menimbulkan rasa gatal. Suasana ruang rawat yang tidak nyaman membuat anak terbangun-saat tidur.

"Kebangun mulu, banyak berisik, ada kayak suara orang ngobrol, ada suara anak nangis... bayinya bangun, nangis, iya bikin susah tidur.... (partisipan 10).

“Gerah, enggak bisa tidur...” (partisipan 8).

"Di ICU dingin, kalau malem dingin banget..." (partisipan 6).

"Ininya bikin sakit (menunjuk bagian pinggir perlak),gatal” (partisipan 7).

“kasurnya keras, bikin pegel” (partisipan 9).

Meskipun demikian, terdapat satu orang anak yang tidak merasakan ketidaknyaman terhadap lingkungan ruang rawat. Kemungkinan anak ini tidak merasakan kegerahan karena tempat tidurnya berada dekat dengan kipas angin. Perlak 
pelapis tempat tidurnya terpasang rapi dan tidak tampak terlihat bagian yang menyebabkan rasa gatal. Anak ini mengalami keterbatasan mobilisasi karena menderita patah tulang sehingga seprainya terjaga tetap rapi.

Tidak bebas menentukan keinginan. Anak mengalami keterbatasan melakukan aktivitas. Keterbatasan ini disebabkan oleh pemasangan infus dan kurangnya jenis aktivitas dan peralatan untuk bermain. Anak mengatakan bahwa pemasangan infus membatasi pergerakannya. Anak juga mengatakan bosan karena dia lebih banyak tidur dan tidak ada aktivitas lainnya.

"Enggak bisa bergerak bebas, kalau bergerak ketarik-tarik terus.....( partisipan 6).

"Bosen, enggak bisa nonton tivi" (partisipan 9).

"Bete karena cuma tidur doang terus pengennya jalan-jalan, gitu” (partisipan 10).

Anak juga mengalami kehilangan kontrol untuk memenuhi kebutuhannya, seperti tidur dan makan. Mereka mengatakan tidak bisa tidur saat mengantuk karena adanya anak lain yang menangis, atau dibangunkan karena harus mendapatkan suntikan antibiotik. Anak juga tidak dapat mengontrol menu makan yang sesuai dengan selera makannya. Porsi makan anak berkurang karena nasi terlalu lembek atau jenis lauk yang tidak mereka sukai.

"Kebangun mulu, banyak berisik, bikin susah tidur.... (partisipan 10).

"Iya sih, kadang-kadang disuntik waktu sedang tidur gitu, ngasih obat" (partisipan 10).

"Di sini nasinya lembek banget, enggak enak, masuk, tapi sedikit..."( partisipan 5).

"Ya, ada yang enak, sebagian enggak bagi saya, enggak ngerti, kayak sekali nyicip gitu, langsung mau muntah ....(partisipan 10).

\section{Mengalami nyeri selama perawatan.} Pengalaman merasakan ketidaknyamanan, seperti nyeri yang dirasakan oleh semua anak yang terlibat dalam penelitian ini. Rasa nyeri ini disebabkan oleh proses perjalanan penyakit dan tindakan perawatan seperti pemasangan infus atau pengambilan darah untuk pemeriksaan laboratorium.

"Sakit perut tapi bagian bawah, waktu pipis".." (partisipan 8).

"Disuntik sakit banget gitu, ngilu, he-eh, sampe teriak malah..." (partisipan 10).

\section{Menemukan cara mengatasi masalah selama}

dirawat. Mengalami sakit dan menjalani prosedur pengobatan mengajarkan anak memiliki kemampuan untuk mengatasi stresor yang dihadapinya. Anak mengatakan bahwa ia tidur-tiduran atau main game dulu untuk mengurangi mual saat makan. Anak mengakui strategi itu ia dapatkan sendiri dan bukan dari orang tuanya.

"Kalau mual makannya berhenti dulu, tidurtiduran dulu, atau main game dulu, baru makan lagi..." ( partisipan 6).

Berinteraksi dengan petugas kesehatan dan menjalani prosedur pengobatan juga memberikan kesadaran tentang kesehatan dan upaya mencegah dan mengobati penyakit yang dialaminya.

"Jangan jajan sembarangan lagi, biar ususnya gak infeksi” (partisipan 6).

"Diinfus, buat ngasih cairan biar sehat..." (partisipan 2).

\section{Pembahasan}

Penelitian ini menemukan lima tema pengalaman hospitalisasi pada anak, yaitu terbatasnya melakukan aktivitas rutin sehari-hari, suasana ruang rawat tidak nyaman, tidak bebas menentukan keinginan, mengalami nyeri selama perawatan, dan menemukan cara mengatasi masalah selama dirawat.

Mengalami keterbatasan melakukan aktivitas rutin sehari-hari yang didapatkan dalam penelitian 
ini juga ditemukan oleh banyak penelitian sebelumnya (Coyne, 2006; Wilson, Megel, Enenbach dan Carlson, 2010; Bsiri-Moghaddam, Basiri-Moghaddam, Sadeghmogaddam, \& Ahmadi, 2011). Hasil penelitian ini sama dengan hasil penelitian Coyne (2006) yang menyatakan bahwa hospitalisasi menyebabkan anak terpisah dari anggota keluarga, teman bermain, aktivitas rutin anak, dan pencapaian prestasi sekolah. Penelitian ini juga mendapatkan temuan yang sama dengan penelitian oleh Bsiri-Moghaddam, et al., (2011), yaitu keterbatasan interaksi dengan orang tua masih menjadi permasalah utama pada anak berusia sekolah. Padahal perpisahan dengan orang tua seharusnya tidak menjadi masalah utama pada anak usia sekolah (Wong \& Hockenberry, 2003).

Dampak negatif dari terbatasnya interaksi dan terpisah dengan keluarga, teman bermain, dan aktivitas rutin sehari-hari dapat dicegah dengan memaksimalkan kontak anak dengan keluarga, teman, dan sekolah (Coyne, 2006). Upaya ini dapat dilakukan dengan menambah jam kunjungan terutama kunjungan keluarga, menyediakan ruang untuk bermain dan peralatan bermain, serta memfasilitasi anak untuk bermain dengan pasien lainnya (Wilson, et al., 2010). Bermain merupakan kebutuhan dasar bagi anak. Anak menyatakan bahwa aktivitas yang paling menyenangkan selama hospitalisasi adalah aktivitas yang menghibur, seperti bermain video dan menonton video (Pelander \& Leino-Kilpi, 2010).

Tema lainnya yang juga dialami oleh semua anak adalah suasana ruang rawat tidak nyaman. Tema ini juga ditemukan pada penelitian oleh Coyne (2006) dan Salmela, Aronen, dan Salantera (2010). Penyebab pengalaman suasana ruang rawat tidak nyaman dalam penelitian ini sama dengan penyebab pada penelitian Coyne (2006). Ketidaknyamanan pada ruang rawat tersebut adalah kebisingan ruangan, suhu ruangan yang panas, fasilitas yang tidak adekuat, silau pada malam hari, dan makanan. Bsiri-Moghaddam, et al., (2011) menambahkan bahwa selain faktorfaktor yang telah disebutkan di atas, penyebab ketidaknyamanan lainnya adalah peraturan rumah sakit dan jam kunjungan. Coyne (2006) menyaran- kan perlunya pengaturan ruang rawat dengan lebih berfokus kepada kenyamanan anak dan bukan kepada kenyamanan petugas kesehatan.

Tema lain yang juga dialami oleh semua anak adalah tidak bebas menentukan keinginan. Timbulnya ketidakbebasan menentukan keinginan dalam penelitian ini sama dengan yang didiskusikan oleh Coyne (2006), yaitu karena adanya hambatan melakukan aktivitas, hambatan memenuhi kebutuhannya, serta tidak dapat mengontrol keinginan tidur dan makan. Strategi yang dapat digunakan untuk mengurangi dampak tersebut dapat dilakukan dengan menghargai anak sebagai seorang individu. Setiap tindakan perawatan terhadap anak harus melibatkan anak sebagai partisipan aktif. Strategi lainnya adalah dengan memberi kesempatan pada anak untuk menentukan waktu pelaksanaan suatu prosedur yang diinginkannya (Wilson, et al., 2010).

Tema mengalami nyeri selama perawatan dalam penelitian ini juga ditemukan dalam penelitian Coyne (2006) dan Bsiri-Moghaddam, et al. (2011). Ketakutan mengalami nyeri karena prosedur pengobatan merupakan pengalaman yang paling tidak disukai anak (Pelander \& Leino-Kilpi, 2010). Ketakutan terhadap prosedur yang menyakitkan dapat dikurangi dengan mempersiapkan anak sebelum prosedur dilakukan. Persiapan harus dilakukan sesuai dengan tahapan usia anak (Coyne, 2006). Melakukan prosedur perawatan sambil bermain terapi efektif untuk mengurangi ketakutan anak. Bermain seharusnya selalu dilakukan selama proses perawatan anak dan disesuaikan dengan kondisi penyakit anak (Wilson, et al., 2010).

Tema terakhir dalam penelitian ini adalah anak dapat menemukancara mengatasi masalahnya selama dirawat. Selama perawatan, anak belajar menemukan koping untuk mengatasi ketakutan dan kecemasannya. Anak akan merasakan kepuasan ketika mereka mampu menemukan koping untuk mengatasi ketakutan dan kecemasannya. Pada akhirnya, hal ini akan menumbuhkan rasa percaya diri. Berinteraksi dengan petugas kesehatan dapat meningkatkan pengetahuan anak tentang penyakit yang dideritanya dan upaya 
untuk pengobatan dan pencegahannya. Dampak lebih lanjut berkomunikasi dan interaksi dengan pertugas kesehatan mungkin akan memberikan ketertarikan terhadap pemilihan karir masa depan di bidang kesehatan (James \& Ashwill, 2007). Selain itu, pengalaman hospitalisasi akan memengaruhi pemanfaatan sarana kesehatan di masa mendatang. Pengalaman hospitalisasi yang traumatik menyebabkan keengganan dan ketakutan untuk menggunakan fasilitas kesehatan untuk menjaga dan mempertahankan kesehatan (Ryan-Wegner \& Gardner, 2012).

\section{Kesimpulan}

Hospitalisasi dapat memberikan pengalaman menyedihkan dan menyenangkan bagi anak. Mengalami sakit dan dirawat di rumah sakit membuat anak mengalami perpisahan dengan keluarga, teman bermain, serta keterbatasan melakukan aktivitas yang biasa mereka lakukan bersama keluarga dan teman bermainnya. Lingkungan yang asing dan tidak nyaman, mengalami kehilangan kontrol diri, ketidakberdayaan, dan merasakan nyeri merupakan pengalaman tidak menyenangkan lainnya yang anak rasakan selama perawatanya.

Meskipun demikian, hospitalisasi dapat memberikan dampak positif bagi anak. Kemampuan anak mengatasi ketakutan dan kecemasannya selama perawatan dapat meningkatkan rasa percaya diri anak. Selain itu, hospitalisasi akan membukakan wawasan tentang kesehatan dan kemungkinan karier di bidang kesehatan. Penelitian ini merekomendasikan perlunya pemahaman tentang tumbuh kembang anak dan teknik komunikasi dengan anak bagi petugas kesehatan agar hospitalisasi menjadi pengalaman yang memberikan dampak positif bagi anak dan keluarga (HW, YR, PN).

\section{Ucapan Terima Kasih}

Ucapan terima kasih diberikan kepada Direktorat Riset dan Pngabdian Masyarakat Universitas Indonesia (DRPM UI) yang telah memberikan dana bagi terlaksananya penelitian ini.

\section{Referensi}

Bowden, B.R., \& Greenberg, C.M. (2010). Children and their families: Continuum of care. Second edition. Philadephia: Lippincott Willian \& Wilkins.

Bsiri-Moghaddam, K., Basiri-Moghaddam, M., Sadeghmoghaddam, L., \& Ahmadi, F. (2011). The concept of hospitalization of children from the point of view of parents and children. Iranian Journal of Pediatric, 21, 2, 201-208.

Coyne, I. (2006). Children's experiences of hospitalization. Journal of Child Health Care, $10,4,326-336$.

James, S.R. \& Ashwil, J.W. (2007). Nursing care of children: Principle \& practice. United of America: Saunders Elsevier.

Karlings, M. (2006). Child behaviour and pain after hospitalization, surgey, and anaesthesia. UMEA. Sweden: University medical dissertation.

Pelander, T., \& Leino-Kilpi, H. (2010). Children's best and worst experiences during hospitallization. Scandinavian Journal of Caring Sciences, 24, 726-733.

Rautava, P., Lehtonen, L., Heleneus, H., \& Sillanpaa, M. (2003). Effects of newborn hospitalization on family and child behaviour: A 12-year follow-up study. Pediatrics, 111, 277-283.

Ryan-Wegner, N.A. \& Gardner, W. (2012). Hospitalized children's perspective on the quality and equity of the nursing care. Nursing Care Quality, 27, 1, 35-42.

Salmela, M., Aronen, E. T., \& Salentera, S. (2010). The experience of hospital-related fear of 4-6 year old children.Child: Care, Health and Development. 37, 5, 719-726.

Wong, D.L., \& Hockenberry, M.J. (2003). Wong's nursing care of infants and children. (7th Ed.). USA: Mosby company.

Wilson, M.E., Megel, M.E., Enenbach, L., \& Carlson, K.L. (2010). The voice of children: stories about hospitalization. Journal of Pediatric Health Care, 24, 95-102. 